\section{Landscape Performance of Green Fountain Grass Alternatives Grown in Northern and Southern Florida}

\author{
Sandra B. Wilson ${ }^{1,3}$ and Gary W. Knox ${ }^{2}$
}

AdDitional InDEX wORDs. cultivar trials, ornamental, invasive, Pennisetum alopecuroides, Pennisetum messiacum, Pennisetum orientale, Pennisetum setaceum

Summary. Plant growth, visual quality, flowering, and seed production were assessed for 10 fountain grass (Pennisetum) cultivars planted in northern and southern Florida. All fountain grass cultivars except Rubrum Dwarf fountain grass (Pennisetum setaceum) and Red Buttons fountain grass (Pennisetum messiacum) achieved flower ratings of 3 to 5 in both locations during the first growing season. During the second growing season, chinese fountain grass (Pennisetum alopecuroides), 'Cassian' chinese fountain grass ( $P$. alopecuroides), 'Hameln' chinese fountain grass ( $P$. alopecuroides), and 'Red Buttons' fountain grass flowered better in northern Florida, and green fountain grass ( $P$. setaceum) and 'Rubrum Dwarf' fountain grass flowered better in southern Florida. Visual quality of chinese fountain grass and its cultivars generally declined in October without resuming growth through May. 'Little Bunny' chinese fountain grass ( $P$. alopecuroides) and oriental pennisetum (Pennisetum orientale) declined dramatically during the first season and did not survive the 84-week study in northern or southern Florida. 'Rubrum' fountain grass ( $P$. setaceum) and 'Rubrum Dwarf' fountain grass did not produce any seeds.

$\mathrm{T}$ he state of Florida is the second largest producer of ornamental plants in the United States, with total industry sales in 2005 estimated at $\$ 15.2$ billion (Hodges and Haydu, 2006). The use of ornamental grasses in median strips, parking lot borders, and for erosion control on slopes has become increasingly popular over the years. Modern grass cultivars offer a broad range of characteristics to choose from, such as flowering time, panicle size, leaf width and color, and plant form. Of the many ornamental Poaceae genera, Pennisetum is among the very popular (Darke, 1999; Gilman, 2007; Grounds, 1998). Desirable attributes of Pennisetum are its long flower cycle and adaptability to a range of landscape conditions; yet a

Indian River Research and Education Center Journal Series No. R-060802. This research was supported by the Florida Department of Environmental Protection.

We thank Laurie Mecca, John Zadakis, and Patricia Frey for providing technical assistance throughout the study, and Keona Muller for statistical and graphical interpretation.

${ }^{1}$ Associate Professor, Institute of Food and Agricultural Sciences, Department of Environmental Horticulture, University of Florida, Indian River Research and Education Center, Fort Pierce, FL 34945

${ }^{2}$ Professor, Institute of Food and Agricultural Sciences, Department of Environmental Horticulture, University of Florida, North Florida Research and Education Center, Quincy, FL 32351

${ }^{3}$ Corresponding author. E-mail: sbwilson@ufl.edu. consequence of this is its ability to self-seed and readily naturalize in areas far beyond its planting. Introduced to Hawaii in 1914, green fountain grass has since escaped cultivation in eight states (U.S. Department of Agriculture, 2008), including Florida (three counties) (Wunderlin and Hansen, 2008). It is listed as invasive in California and Arizona, and as a noxious weed in Hawaii (Poulin et al., 2007; Staples et al., 2000; USDA, 2008; Williams et al., 2002). As an extremely aggressive colonizer, it is also problematic in other parts of the world including, the Canary Islands, New Zealand, and Australia (Csurhes and Edwards, 1998; Pacific Island Ecosystems at Risk, 2007).

Florida's Exotic Pest Plant Council (FLEPPC) lists green fountain grass as a Category II invasive, indicating that it has increased in abundance or frequency, but has not yet altered Florida plant communities to the extent shown by Category I species (Florida Exotic Pest Plant Council, 2007). In 2003, The University of Florida (UF) Institute of Food and Agricultural Sciences (IFAS) Status Assessment of Non-native Plants (Fox et al., 2008) suggested that green fountain grass is not currently a problem species in Florida's natural areas, although it was documented in undisturbed natural areas in central Florida. These conclusions were footnoted to emphasize that there was insufficient evidence to fully validate the statement (Fox et al., 2008).

As alternatives to the resident species (wild-type form) of green fountain grass, there are several other closely related species that have ornamental value, such as chinese fountain grass, 'Red Buttons' fountain grass, and oriental pennisetum. In addition, although breeding efforts to improve fountain grass have not been extensive (Meyer and White, 1994; Simpson and Bashaw, 1969), there are at least 10 known cultivars of chinese fountain grass and two known cultivars of green fountain grass (Darke, 1999). The overall objective of this study was to evaluate plant performance, growth, and flowering of 10 fountain grass cultivars planted in southern Florida (Fort Pierce, USDA Plant Hardiness Zone 9b) and northern Florida (Quincy, USDA Plant Hardiness Zone 8b).

\section{Materials and methods}

Plant material and Field CONDITIONS. Ten fountain grass cultivars were selected for this study based on popularity and availability (Table 1). Clonally propagated cultivars were obtained as liners from Emerald Coast Growers (Pensacola, FL) and were finished in 1.0-gal containers at the North Florida Research and Education Center (Quincy, FL). Nine uniform 1.0-gal plants of each selection were installed in southern Florida (Fort Pierce) and northern Florida (Quincy) on 11 June 2003.

\begin{tabular}{llll}
\hline $\begin{array}{l}\text { Units } \\
\begin{array}{l}\text { To convert U.S. to SI, } \\
\text { multiply by }\end{array}\end{array}$ & U.S. unit & SI unit & $\begin{array}{l}\text { To convert SI to U.S., } \\
\text { multiply by }\end{array}$ \\
\hline 0.3048 & $\mathrm{ft}$ & $\mathrm{m}$ & 3.2808 \\
3.7854 & $\mathrm{gal}$ & $\mathrm{L}$ & 0.2642 \\
2.54 & inch $(\mathrm{es})$ & $\mathrm{cm}$ & 0.3937 \\
25.4 & inch $(\mathrm{es})$ & $\mathrm{mm}$ & 0.0394 \\
8.3495 & $\mathrm{oz}$ & $\mathrm{g}$ & 0.0353 \\
$\left({ }^{\circ} \mathrm{F}-32\right) \div 1.8$ & ${ }^{\circ} \mathrm{F}$ & ${ }^{\circ} \mathrm{C}$ & $\left(1.8 \times{ }^{\circ} \mathrm{C}\right)+32$
\end{tabular}


Table 1. Nomenclature and plant description of 10 fountain grass species and cultivars. Plant hardiness zone is based on the U.S. Department of Agriculture zone map (USDA, 2003), as referenced by Loewer (2003) and Greenlee (1992). Plant form is based on categories described by Greenlee (1992). Foliage and inflorescence descriptions are based on observations in Florida.

\begin{tabular}{|c|c|c|c|c|}
\hline Common name & $\begin{array}{c}\text { Pennisetum } \\
\text { species }\end{array}$ & $\begin{array}{l}\text { Plant } \\
\text { hardiness } \\
\text { zone }\end{array}$ & $\begin{array}{l}\text { Plant } \\
\text { form }\end{array}$ & Foliage and inflorescence description \\
\hline $\begin{array}{l}\text { Chinese fountain } \\
\text { grass }\end{array}$ & P. alopecuroides & $6-9$ & $\begin{array}{l}\text { Upright } \\
\text { divergent }\end{array}$ & $\begin{array}{l}\text { Leaves emerge in early spring and are followed in late } \\
\text { summer by whitish, foxtail-like inflorescences that } \\
\text { darken with age. Height of inflorescences ranges from } \\
\text { just above the foliage to about } 1.25 \text { times the plant } \\
\text { height. Foliage and inflorescences senesce and turn } \\
\text { tan-colored by mid-fall. }\end{array}$ \\
\hline $\begin{array}{c}\text { 'Cassian' chinese } \\
\text { fountain grass }\end{array}$ & P. alopecuroides & & Tufted & $\begin{array}{l}\text { Smaller form of the species. Leaves emerge in mid-spring } \\
\text { and inflorescences develop in midsummer, emerging } \\
\text { whitish and aging to beige. Inflorescences are held just } \\
\text { above the foliage. Leaves and inflorescences turn } \\
\text { tan-colored by mid-fall. }\end{array}$ \\
\hline $\begin{array}{l}\text { 'Hameln' chinese } \\
\text { fountain grass }\end{array}$ & P. alopecuroides & & $\begin{array}{l}\text { Tufted to } \\
\text { upright } \\
\text { divergent }\end{array}$ & $\begin{array}{l}\text { Dwarf form of the species with more narrow leaves. New } \\
\text { growth emerges in late spring and is followed in early } \\
\text { summer by inflorescences that are whitish to pale pink, } \\
\text { aging to beige. Inflorescences are held just above foliage. }\end{array}$ \\
\hline $\begin{array}{l}\text { 'Little Bunny' } \\
\text { chinese fountain } \\
\text { grass }\end{array}$ & P. alopecuroides & & Tufted & $\begin{array}{l}\text { Less vigorous, very dwarf form of the species. Plants develop } \\
\text { whitish inflorescences that age to beige. Inflorescences are } \\
\text { held just above the foliage. Inflorescences and leaves turn } \\
\text { tan-colored by early fall. }\end{array}$ \\
\hline $\begin{array}{l}\text { 'Moudry' chinese } \\
\text { fountain grass }\end{array}$ & P. alopecuroides & & Mounded & $\begin{array}{l}\text { Leaves are wider than the species and emerge in mid- to } \\
\text { late spring. Inflorescences develop in early fall just above } \\
\text { the foliage and are dark brown to black. Leaves turn } \\
\text { tan-colored by mid to late fall. }\end{array}$ \\
\hline $\begin{array}{l}\text { 'Red Buttons' } \\
\text { fountain grass }\end{array}$ & P. messiacum & $7-9$ & $\begin{array}{l}\text { Tufted to } \\
\text { arching }\end{array}$ & $\begin{array}{l}\text { Leaves emerge in early spring and are quickly followed } \\
\text { by whitish inflorescences aging to pink and beige. } \\
\text { Inflorescences are displayed above the foliage about } \\
1.5 \text { times the plant height. Leaves and inflorescences } \\
\text { senesce and turn tan-colored by late summer. }\end{array}$ \\
\hline $\begin{array}{l}\text { 'Rubrum' fountain } \\
\text { grass }\end{array}$ & P. setaceum & & $\begin{array}{l}\text { Upright } \\
\text { arching }\end{array}$ & $\begin{array}{l}\text { Burgundy leaves emerge late spring to early summer. Dark } \\
\text { pink inflorescences form from midsummer to early fall, } \\
\text { aging to pale pink. Height of inflorescences ranges from } \\
\text { just above the foliage to about } 1.25 \text { times the plant height. }\end{array}$ \\
\hline $\begin{array}{l}\text { 'Rubrum Dwarf' } \\
\text { fountain grass }\end{array}$ & P. setaceum & & Tufted & $\begin{array}{l}\text { Smaller, less vigorous form of 'Rubrum'. Pale pink } \\
\text { inflorescences are held just above the foliage and age to } \\
\text { white. Leaves and inflorescences turn tan-colored by } \\
\text { mid-fall. }\end{array}$ \\
\hline
\end{tabular}

${ }^{2}$ Green fountain grass (P. setaceum) is listed by the Florida Exotic Pest Plant Council (FLEPPC) as a Category II invasive in southern Florida (Florida Exotic Pest Plant Council, 2007).

Plants were placed $4.0 \mathrm{ft}$ on center in beds covered with black landscape fabric. Plants were subirrigated by filling canals (southern Florida) or drip irrigated (northern Florida) as needed (generally three times per week in the spring and fall and once per week in the winter and summer). Plants were fertilized 4 and 56 weeks after planting with $2 \mathrm{oz}$ of 12 -month $15 \mathrm{~N}-3.9 \mathrm{P}-$ 10K Osmocote Plus (Scotts, Marysville, $\mathrm{OH}$ ) in the area 12 to 18 inches from the crown. Daily rainfall, temperature, and solar radiation were recorded at each site by Florida Automated Weather Network (FAWN) monitoring stations located at or near the sites. Field conditions for southern Florida were as follows: Ankona sand with $1.3 \%$ organic matter, $\mathrm{pH} 5.7$, average monthly rainfall $11.03 \mathrm{~cm}$, 
mean minimum and maximum temperatures 12.7 and $32.1{ }^{\circ} \mathrm{C}$, respectively, and $77.9 \%$ relative humidity. Field conditions for northern Florida were as follows: Carnegie loamy fine sand with $2.0 \%$ organic matter, $\mathrm{pH}$ 5.0 , average monthly rainfall 11.14 $\mathrm{cm}$, mean minimum and maximum temperatures 7.6 and $31.2^{\circ} \mathrm{C}$, respectively, and $79.3 \%$ relative humidity.

Visual Quality, Flowering, AND PLANT GROWTH. Visual quality (plant color and form) was assessed monthly by three individuals for each cultivar independently at each location. Assessments of foliage color and form were performed on a scale from 1 to 5 where 1 = poor quality, not acceptable, severe leaf necrosis or yellowing, 2 = fair quality, marginally acceptable, some areas of necrosis or yellowing, 3 = average quality, adequate and somewhat desirable form and color, 4 = good quality, very acceptable and desirable color and form, and 5 = excellent quality, very desirable landscape performance. On 15 Feb. 2004, plants at each location were cut back to 6 to 8 inches aboveground in accordance with industry standards. Values for the highest rating, peak month, and cumulative average rating were generated from data collected during monthly evaluations (not presented).

Monthly assessments of flower coverage (percentage of flower spikes in relation to foliage) were performed on a scale from 1 to 5 where $1=0 \%$ (no flowers present), $2=25 \%, 3=$ $50 \%, 4=75 \%$, and $5=100 \%(\max -$ imum canopy coverage). Following peak flower production (a time determined when greater than half of the inflorescences faded and were fully mature), the total inflorescence number per plant was recorded at each location. At the termination of the study (week 84, 13 Jan. 2005), growth indices were calculated for each plant as an average of the measured height (measured from crown to natural break in foliage) and two perpendicular widths. Crown circumference was measured 1 inch above the soil level.

EXPERIMENTAL DESIGN AND STATISTICAL ANALYSIS. The field experiments were conducted similarly in northern and southern Florida. A randomized complete block experimental design was used with 10 cultivars placed in three-plant plots replicated three times (blocks). Visual quality and flowering data were collected monthly for each replication. At 84 weeks, growth data were collected on each plant sample. Each experiment was subjected to analysis of variance, and significant means separated by least significant difference at $P=0.05$.

\section{Results and discussion}

VISUAL QUALITY AND PLANT GROWTH. The visual quality of fountain grass varied by location and cultivar (Table 2). In southern Florida, plants generally remained evergreen throughout the study. Peak visual quality values were recorded from June to September of the first growing season and were generally high (very good to excellent) among cultivars, with the exception of 'Red Buttons' fountain grass, which had a slightly lower peak rating of 3.4 (Table 2). It should be noted that some decline in plant performance was visually observed in southern Florida during the fall of 2004 following hurricanes Frances (5 Sept.) and Jeanne (26 Sept.), but plants recovered. Overall, green fountain grass and 'Rubrum' fountain grass had higher average visual quality ratings, suggesting that they performed better for longer than the other

Table 2. Maximum visual quality rating, peak time (based on plant color and form), and overall average rating of 10 fountain grass species or cultivars grown in northern and southern Florida for 84 weeks.

\begin{tabular}{|c|c|c|c|c|c|c|}
\hline \multirow[b]{2}{*}{ Species or cultivar } & \multicolumn{3}{|c|}{ Southern Florida } & \multicolumn{3}{|c|}{ Northern Florida } \\
\hline & $\begin{array}{c}\text { Highest } \\
\text { rating } \\
(1-5 \text { scale })^{z} \\
\end{array}$ & $\begin{array}{c}\text { Peak } \\
\text { months(s) } \\
\text { and year(s) }\end{array}$ & $\begin{array}{c}\text { Average } \\
\text { rating } \\
(1-5 \text { scale })^{y} \\
\end{array}$ & $\begin{array}{l}\text { Highest } \\
\text { rating } \\
(1-5 \text { scale })^{z}\end{array}$ & $\begin{array}{c}\text { Peak } \\
\text { months(s) } \\
\text { and year(s) }\end{array}$ & $\begin{array}{c}\text { Average } \\
\text { rating } \\
(1-5 \text { scale })^{\mathrm{y}} \\
\end{array}$ \\
\hline Chinese fountain grass & 5.0 & $\begin{array}{l}\text { July } 2003, \\
\text { August } 2003\end{array}$ & 2.2 & 4.7 & September 2003 & 2.3 \\
\hline $\begin{array}{l}\text { 'Cassian' chinese } \\
\text { fountain grass }\end{array}$ & 5.0 & $\begin{array}{l}\text { June } 2003, \\
\text { July } 2003\end{array}$ & 2.4 & 4.2 & August 2003 & 2.1 \\
\hline $\begin{array}{l}\text { 'Little Bunny' } \\
\text { chinese fountain grass }\end{array}$ & 4.9 & July 2003 & 1.6 & 3.9 & August 2003 & 1.4 \\
\hline $\begin{array}{l}\text { 'Moudry' chinese } \\
\text { fountain grass }\end{array}$ & 4.6 & September 2003 & 2.0 & 3.2 & October 2003 & 1.5 \\
\hline $\begin{array}{l}\text { 'Red Buttons' } \\
\text { fountain grass }\end{array}$ & 3.4 & July 2003 & 1.7 & 3.2 & July 2003 & 1.9 \\
\hline 'Rubrum' fountain grass & 5.0 & June 2003 & 3.4 & 5.0 & $\begin{array}{l}\text { September } 2003, \\
\text { October } 2003\end{array}$ & 2.8 \\
\hline $\begin{array}{l}\text { 'Rubrum Dwarf' fountain } \\
\text { grass }\end{array}$ & 4.4 & June 2003 & 2.0 & 2.3 & $\begin{array}{l}\text { June } 2003, \\
\text { October } 2003\end{array}$ & 1.3 \\
\hline $\operatorname{LSD}(0.05)^{\mathrm{x}}$ & 0.6 & & 0.6 & 0.5 & & 0.3 \\
\hline
\end{tabular}

${ }^{\mathrm{z}}$ Level of performance was rated 1 (poor quality) to 5 (excellent).

y Average rating was derived by dividing the cumulative monthly quality rating by 21 months.

${ }^{x}$ Least significant difference at $P=0.05$. 
cultivars (Table 2). As predicted for warm season grasses, visual quality often peaked a month or more earlier in southern Florida than in northern Florida (Table 2).

In northern Florida, frost killed aboveground portions of all plants during both winters. Peak visual quality values were recorded from June to October of the first growing season and were generally high (good to excellent) among cultivars, with the exception of 'Moudry' chinese fountain grass ( $P$. alopecuroides), 'Red Buttons' fountain grass, oriental pennisetum, and 'Rubrum Dwarf' fountain grass, which had slightly lower peak ratings (3.5 or less). 'Rubrum' fountain grass had the highest average visual quality rating in northern Florida, indicating that it performed better for longer than the other cultivars (Table 2).

Regardless of planting site, within the first 6 months of the study (June-December), the visual quality of 'Hameln' chinese fountain grass, 'Little Bunny' chinese fountain grass, 'Moudry' chinese fountain grass, oriental pennisetum, and 'Rubrum Dwarf fountain grass dramatically declined without significantly recovering during the second growing season (monthly data not presented). 'Little Bunny' chinese fountain grass and oriental pennisetum did not survive the 84-week study in either location. 'Hameln' chinese fountain grass and 'Red Buttons' fountain grass survived in northern Florida only and 'Rubrum Dwarf' fountain grass survived in southern Florida only (Table 3). To our knowledge, cultivar trials specific only to the genus Pennisetum have not been previously reported. From much broader ornamental grass trials consisting of numerous genera, Ruter and Carter (2000) reported that 'Hameln' chinese fountain grass and 'Moudry' chinese fountain grass performed well in south-central Georgia (USDA Plant Hardiness Zone 8a). Also, Thetford and Norcini (2009) reported 'Hameln' chinese fountain grass to perform better than 'Moudry' chinese fountain grass (which did not survive the first winter in northern
Florida or the second winter in northwestern Florida).

Of the fountain grass cultivars evaluated in southern Florida, after 84 weeks, 'Rubrum' fountain grass was the tallest with the greatest growth index, but green fountain grass had the greatest crown circumference (Table 3 ). In northern Florida, 'Rubrum' fountain grass and green fountain grass were similarly tall; green fountain grass had the greatest growth index, and chinese fountain grass and green fountain grass had the greatest crown circumference. Among the fountain grass cultivars evaluated, growth was generally greater in northern Florida than in southern Florida, with the exception of 'Moudry' chinese fountain grass and 'Rubrum Dwarf' fountain grass (Table 3 ).

FLOWERING. Flowering performance varied by cultivar and location (Fig. 1, Table 3). Although considered annuals in most parts of the southeastern United States (Loewer, 2003), green fountain grass and its cultivars generally performed as perennials in

Table 3. Average panicle number at 64 weeks and plant height, growth index, crown circumference, and mortality rate at 84 weeks for 10 fountain grass species or cultivars grown in southern and northern Florida.

\begin{tabular}{|c|c|c|c|c|c|c|c|c|c|c|}
\hline \multirow[b]{2}{*}{$\begin{array}{l}\text { Species or } \\
\text { cultivar }\end{array}$} & \multicolumn{2}{|c|}{$\begin{array}{l}\text { Inflorescence at } 64 \\
\text { weeks (panicle no.) }\end{array}$} & \multicolumn{2}{|c|}{ Plant ht $(\mathrm{cm})^{\mathrm{z}}$} & \multicolumn{2}{|c|}{$\begin{array}{c}\text { Growth index } \\
(\mathrm{cm})\end{array}$} & \multicolumn{2}{|c|}{$\begin{array}{c}\text { Crown } \\
\text { circumference } \\
(\mathrm{mm})^{\mathrm{y}}\end{array}$} & \multicolumn{2}{|c|}{$\begin{array}{l}\text { Mortality after } \\
84 \text { weeks (\%) }\end{array}$} \\
\hline & $\begin{array}{l}\text { Southern } \\
\text { Florida }\end{array}$ & $\begin{array}{c}\text { Northern } \\
\text { Florida }\end{array}$ & $\begin{array}{l}\text { Southern } \\
\text { Florida }\end{array}$ & $\begin{array}{c}\text { Northern } \\
\text { Florida }\end{array}$ & $\begin{array}{l}\text { Southern } \\
\text { Florida }\end{array}$ & $\begin{array}{c}\text { Northern } \\
\text { Florida }\end{array}$ & $\begin{array}{l}\text { Southern } \\
\text { Florida }\end{array}$ & $\begin{array}{c}\text { Northern } \\
\text { Florida }\end{array}$ & $\begin{array}{c}\text { Southern } \\
\text { Florida }\end{array}$ & $\begin{array}{c}\text { Northern } \\
\text { Florida } \\
\end{array}$ \\
\hline $\begin{array}{l}\text { Chinese fountain } \\
\text { grass }\end{array}$ & 59.0 & 152.4 & 40.0 & 53.8 & 42.3 & 66.2 & 73.7 & 101.2 & 89 & 22 \\
\hline $\begin{array}{l}\text { 'Hameln' chinese } \\
\text { fountain grass }\end{array}$ & $-^{x}$ & $-^{x}$ & $-^{x}$ & 28.0 & $-^{x}$ & 34.3 & $-^{x}$ & 44.0 & 100 & 89 \\
\hline $\begin{array}{l}\text { 'Little Bunny' } \\
\text { chinese fountain } \\
\text { grass }\end{array}$ & $-^{x}$ & $-^{x}$ & $一^{\mathrm{x}}$ & $-^{x}$ & $一^{\mathrm{x}}$ & $-^{\mathrm{x}}$ & $一^{x}$ & $-^{\mathrm{x}}$ & 100 & 100 \\
\hline $\begin{array}{l}\text { 'Moudry' chinese } \\
\text { fountain grass }\end{array}$ & 94.7 & 28.3 & 27.5 & 25.3 & 28.6 & 27.9 & 54.9 & 33.0 & 67 & 56 \\
\hline $\begin{array}{l}\text { Green fountain } \\
\text { grass }\end{array}$ & 171.8 & 119.0 & 52.9 & 95.0 & 54.0 & 97.3 & 97.4 & 89.0 & 11 & 78 \\
\hline $\begin{array}{l}\text { 'Rubrum' fountain } \\
\text { grass }\end{array}$ & 188.7 & 36.0 & 65.6 & 90.5 & 58.2 & 71.1 & 72.1 & 64.3 & 0 & 56 \\
\hline $\begin{array}{l}\text { 'Rubrum Dwarf' } \\
\text { fountain grass }\end{array}$ & 27.0 & $-^{x}$ & 21.7 & $-^{x}$ & 22.4 & $-^{x}$ & 51.6 & $-^{x}$ & 56 & 100 \\
\hline $\operatorname{LSD}(0.05)^{\mathrm{w}}$ & 118.2 & 75.4 & 12.2 & 13.5 & 14.9 & 16.1 & 18.7 & 33.6 & 46.4 & 41.6 \\
\hline
\end{tabular}

${ }^{\mathrm{z}} 1 \mathrm{~cm}=0.3937$ inch

${ }^{\mathrm{y}} 1 \mathrm{~mm}=0.0394$ inch.

${ }^{x}$ No plants survived the experiment.

weast significant difference at $P=0.05$. 
chinese fountain grass

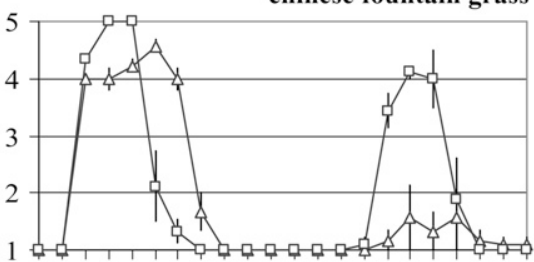

'Hameln' chinese fountain grass
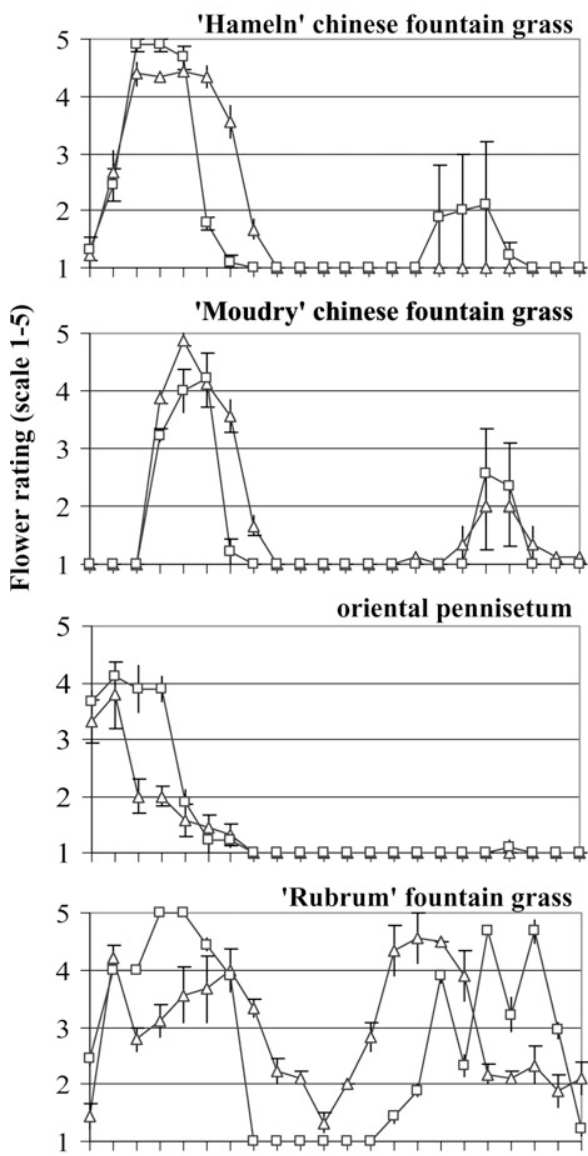

June Sept. Nov. Feb. May July Oct. Jan. June Sept. Nov. Feb. May July Oct. Jan.

Month

Fig. 1. Monthly flower canopy coverage (percentage of flowering canopy) of 10 fountain grass species or cultivars planted in southern $(-\triangle-)$ and northern (一 $\square)$ Florida. Flower canopy coverage was rated $1(0 \%$ coverage $)$ to $5(100 \%$ coverage). Mean values \pm SE are shown $(n=3)$. southern Florida. Within a single counting event at 64 weeks, plants in southern Florida produced an average of $10.6 \%$ more flowers than plants in northern Florida (Table 3). The average inflorescence number ranged from 27 ('Rubrum Dwarf' fountain grass) to 189 ('Rubrum' fountain grass) in southern Florida, or 28 ('Moudry' chinese fountain grass) to 152 (chinese fountain grass) in northern Florida. Regardless of cultivar, peak flowering times were similar in southern and northern Florida during the first growing season (Fig. 1). The time of flower initiation in northern and southern

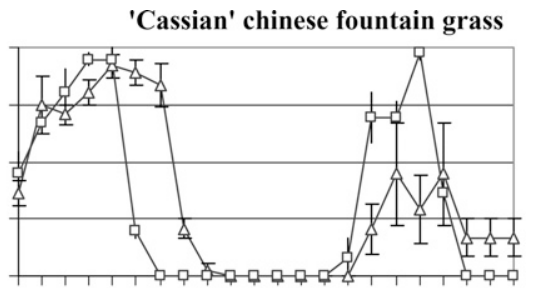

'Little Bunny' chinese fountain grass
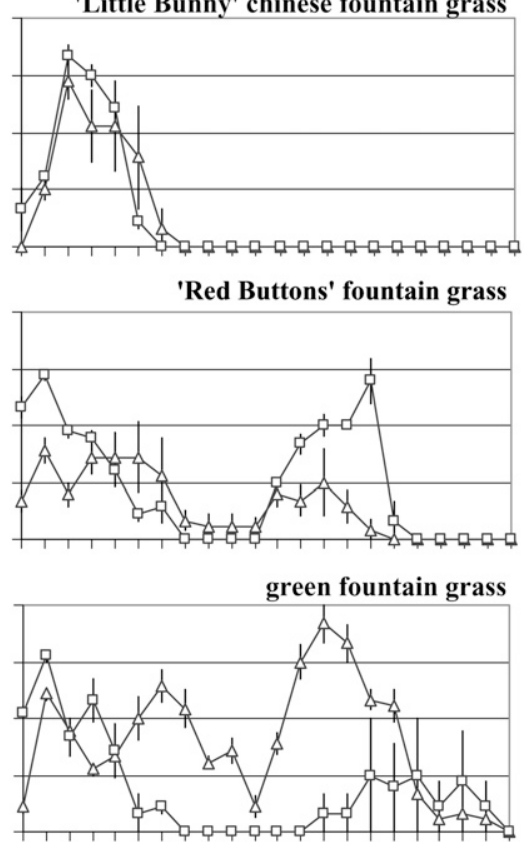

'Rubrum Dwarf' fountain grass

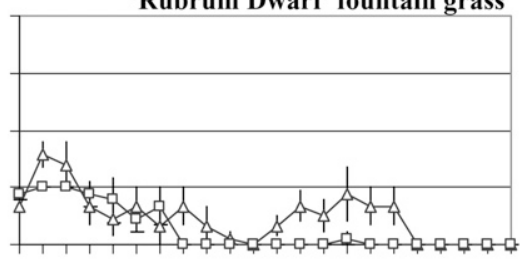

(Wilson and Knox, 2006) and butterfly bush (Buddleja spp.) (Wilson et al., 2004). However, it should be mentioned that 'Rubrum' fountain grass and 'Rubrum Dwarf' fountain grass (both are cultivars of the invasive green fountain grass) did not produce any seeds. This is consistent with Simpson and Bashaw (1969) who reported 'Rubrum' fountain grass to be a sterile hexaploid and current asexual propagation practices that use culm cuttings (Cunliffe et al., 2001) or in vitro regeneration using nodal explants (Meliza and Khatamian, 1998). Meyer and White (1994) reported that in vitro germination can be used to determine pollen viability of chinese fountain grass, but that growth habits influence pollen germination. The cytology and reproductive characteristics of this apomictic genus appear complex (Meyer and White, 1995; Poulin et al., 2007; Simpson and Bashaw, 1969). While further research should address seed production, viability, and seed bank establishment among varying fountain grass cultivars, the results of this ornamental cultivar trial suggest that 'Rubrum' fountain grass (which did not set seeds) performed as well if not better than green fountain grass in southern and northern Florida. Also, in northern Florida, chinese fountain grass, 'Cassian' chinese fountain grass, and 'Red Buttons' fountain grass had similar or better survival and landscape quality compared with green fountain grass throughout the study.

\section{Literature cited}

Csurhes, S. and R. Edwards. 1998. Potential environmental weeds in Australia. National Parks and Wildlife Biodiversity Group, Environment Australia, Canberra, Australia.

Florida generally corresponded to what has been previously reported for the general southeastern United States (Greenlee, 1992; Loewer, 2003). However, flowering of chinese fountain grass, green fountain grass, and their cultivars extended 2 months longer in northern Florida and up to 4 months longer in southern Florida (Fig. 1). Plant mortality and extremely variable or limited seed set among sites and cultivars inhibited us from having enough seeds to conduct appropriate germination studies as performed in previous landscape evaluations of japanese silver grass (Miscanthus sinensis)
Cunliffe, B.A., M.H. Meyer, and P.D. Ascher. 2001. Propagation of Pennisetum setaceum 'Rubrum' from cuttings. J. Environ. Hort. 19:1-3.

Darke, R. 1999. The color encyclopedia of ornamental grasses. Timber Press, Portland, OR.

Florida Exotic Pest Plant Council. 2007. Florida exotic pest plant council's 2007 list of invasive plant species. 1 May 2008. <http://www.fleppc.org/list/07list_ brochure.pdf $>$.

Fox, A.M., D.R. Gordon, J.A. Dusky, L. Tyson, and R.K. Stocker. 2008. IFAS 
assessment of non-native plants in Florida's natural areas-status assessment. 12 Aug. 2008. <http://plants.ifas.ufl.edu/assessment/pdfs/status_assessment.pdfs.

Gilman, E.F. 2007. Pennisetum setaceum tender fountain grass. Univ. Florida Inst. Food Agr. Sci. Fact Sheet FPS-463. 12 Aug. 2008. <http://edis.ifas.ufl.edu/ FP463>.

Greenlee, J. 1992. The encyclopedia of ornamental grasses: How to grow and use over 250 beautiful and versatile plants. Michael Friedman Publishing Group, New York.

Grounds, R. 1998. The plantfinder's guide to ornamental grasses. Timber Press, Portland, OR.

Hodges, A.W. and J.J. Haydu. 2006. Economic impacts of the Florida environmental horticulture industry in 2005. Univ. Florida, Food Resource Econ. Rpt. FE675. 12 Aug. 2008. <http:// economicimpact.ifas.ufl.edu>.

Loewer, P. 2003. Ornamental grasses for the southeast. Cool Springs Press, Thomas Nelson, Nashville, TN.

Meliza, C. and H. Khatamian. 1998. Direct regeneration of Pennisetum setaceum 'Rubrum'. HortScience 33: 462. (Abstr.).

Meyer, M.H. and D.B. White. 1994. In vitro pollen germination in fountain grass. HortScience 29:920.
Meyer, M.H. and D.B. White. 1995. Inheritance of phosphoglucoisomerase in fountain grass. J. Amer. Soc. Hort. Sci. 120:543-547.

Pacific Island Ecosystems at Risk. 2007. Plant threats to pacific ecosystems. 12 Aug. 2008. <http://www.hear.org/ pier/threats.htm>.

Poulin, J., A.K. Sakai, S.G. Weller, and T. Nguyen. 2007. Phenotypic plasticity, precipitation, and invasiveness in the firepromoting grass Pennisetum setaceum (Poaceae). Amer. J. Bot. 94:533-541.

Ruter, J.M. and A.B. Carter. 2000. Ornamental grass evaluations at NESPAL. Proc. Southern Nursery Assn. Res. Conf. 45:398-400.

Simpson, C.E. and E.C. Bashaw. 1969. Cytology and reproductive characteristics in Pennisetum setaceum. Amer. J. Bot. 56: 31-36.

Staples, G.W., D.R. Herbst, and C.T. Imada. 2000. Survey of invasive or potentially invasive cultivated plants in Hawaii. Bishop Museum Press, Honolulu.

Thetford, M. and J.G. Norcini. 2009. Ornamental landscape performance of native and nonnative grasses under low input conditions. HortTechnology 19:267-285.

U.S. Department of Agriculture. 2003. The 2003 US National Arboretum 'web version' of the USDA Plant Hardiness Zone Map. U.S. Dept. Agr. Misc. Publ.
No. 1475, 25 Nov. 2008. <http://www. usna.usda.gov/Hardzone/ushzmap. html>.

U.S. Department of Agriculture. 2008. PLANTS profile: Pennisetum setaceum (Forssk.) Chiov. crimson fountaingrass. 15 May 2008. <http://www.plants.usda. gov/java/nameSearch? keywordquery= pennisetum + setaceum $\&$ mode $=$ sciname $\&$ submit. $x=13 \&$ submit. $y=8>$.

Williams, D.G., R.N. Mack, and R.A. Black. 2002. Ecophysiology of introduced Pennisetum setaceum on Hawaii: The role of phenotypic plasticity. Ecology 76:1569-1580.

Wilson, S.B. and G.W. Knox. 2006. Landscape performance, flowering, and seed viability of fifteen Miscanthus sinensis taxa grown in northern and southern Florida. HortTechnology 24:137-142.

Wilson, S.B., M. Thetford, L.K. Mecca, J.S. Raymer, and J. Gersony. 2004. Evaluation of 14 Buddleja taxa grown in western and southern Florida: II. Seed production and germination. HortTechnology 14:612-618.

Wunderlin, R.P. and B.F. Hansen. 2008. Atlas of Florida vascular plants. 10 May 2008. <http://www.plantatlas.usf.edu/>. 